\title{
К ВОПРОСУ О КРИМИНОЛО-ПСИХОЛОГИЧЕСКОЙ ДИФФЕРЕНЦИАЦИИ НЕСОВЕРШЕННОЛЕТНИХ ПРЕСТУПНИКОВ
}

Автор исследования рассуждает о целесообразности и эффективности типологизации несовершеннолетних преступников. Дифференциация (типологизация) рассматривается в качестве инструмента прогнозирования, минимизации и превенции возможных преступных посягательств в перспективе. Автор предлагает дифференцировать преступников исходя из психолого-мотивационного критерия совершения преступления и выделяет два основных типа преступников: экспансивные (инстинктивные) и консеквентные преступники, каждый из которых дифференцирует на подтипы исходя из особенностей психологического портрета личности, мотивации и идеи как критериев совершения преступления.

Автор предлагает внесение изменений в действующую редакцию статьи 421 Уголовно-процессуального кодекса в контексте возложения обязанности проведения комплексной психолого-психиатрической экспертизы в отношении несовершеннолетнего, ввиду существования многих заболеваний, протекающих латентно и диагностируемых только специалистом.

Автор предлагает создание специализированных социально-педагогических реабилитационных программ в рамках проведения судебно-медицинских экспертиз, к которым следует обращаться правоприменителям при взаимодействии с несовершеннолетним, что, по мнению автора исследования, будет способствовать более эффективной ресоциализации ювенальных преступников.

Также автором высказано предложение о создании специализированных курсов на бесплатной основе, нацеленных на психолого-педагогическую коррекцию несовершеннолетних осужденных, которая будет включать проработку внутренних противоречий, детских травм, закомплексованности и прочих негативных элементов личности. Указанные курсы могут проводиться на базе психиатрических больниц, а в качестве преподавателей (коучеров) могли бы выступать студенты-практиканты.

Таким образом, грамотная типологизация несовершеннолетних преступников, создание благоприятных условий и принятие в купе эффективных мер может способствовать действительному “выздоровлению» лица, вставшего на преступный путь.

Ключевые слова: несовершеннолетние, ювенальная преступность, типологизация, дифференциация, ресоциализация, мотивационный, психологический критерий.

M. E. Kaledin

\section{ON CRIMINOLOGICAL PSYCHOLOGICAL DIFFERENTIATION OF JUVENILE OFFENDERS}

The study discusses the feasibility and effectiveness of the typology of juvenile offenders. Differentiation (typology) is considered as a tool for forecasting, minimizing and preventing possible criminal attacks in the future. The author proposes a typology of criminals based on psychological and motivational criteria of the crime and identifies two main types of criminals: expansive (instinctive) and consequent criminals, each of which differentiates into subtypes based on the characteristics of the psychological portrait of the person, motivation and ideas as criteria for committing a crime.

The author proposes to amend the current version of article 421 of the code of Criminal procedure in the context of imposing the obligation to conduct a comprehensive psychological and psychiatric examination of a minor, due to the existence of many diseases that occur latently and are diagnosed only by a specialist.

The author proposes the development of specialized socio-pedagogical rehabilitation programs in the framework of forensic medical examinations, which should be addressed to law enforcement officers in cooperation with minors which, according to the author of the study, will contribute to a more effective re-socialization of juvenile offenders.

The author also proposed the launch of specialized free courses aimed at psychological and pedagogical correction of convicted minors, which will include the study of internal personal contradictions, children's injuries, complexes and other negative phenomena. These courses can be conducted on the basis of psychiatric hospitals, clinics of border states, and as teachers (coaches) could be students-trainees.

Thus, the competent typology of juvenile offenders, the creation of favorable conditions and the adoption of effective measures in the compartment can contribute to the real "recovery" of a person who has embarked on a criminal path.

Key words: juvenile, juvenile delinquency, classification, differentiation, socialization, motivation, psychological criterion. 
В условиях современной действительности, преступность несовершеннолетних набирает с каждым годом значительные обороты. Изучение феномена «несовершеннолетний преступник» представляет интерес не только для доктрины, но и имеет огромное значение для правоприменения в целом.

По своему составу преступный мир характеризуется широкой пестротой - в социуме сосуществует разнообразное количество преступных типов, изучение которых представляет интерес как с психологической, педагогической точек зрения, так и в культурном отношении. Каждый индивидуум, без исключения, требует к себе сугубо индивидуального подхода со стороны правоприменительных органов, которые, в последние годы, испытывают острую потребность в криминолого-психологических познаниях

Осведомленность правоприменителя о типе того или иного преступника, может помочь ему спрогнозировать поведение последнего, определить, в каком отношении и степени конкретный преступник социально опасен, следовательно, какие меры необходимо предпринять для защиты общества от вероятного последующего преступного посягательства.

Систематизация информации, дифференциация несовершеннолетних преступников на типы, выявление признаков, черт и особенностей, могла бы оказать помощь правоприменителю в контексте минимизации преступности и улучшения качества рассмотрения уголовных дел в судах общей юрисдикции.

Для принятия решения о том, какие меры целесообразно применить к тому или иному несовершеннолетнему преступнику в целях его «ликвидации» с преступного пути, необходимо владеть информацией о первопричине, т.е. знать, что конкретно в личности явилось корнем преступления послужило неким рычагом и каким изменениям должны подвергнуться эти негативные элементь личности с целью достижения необходимой личностной трансформации на благо ювенального преступника и социума.

Для разрешения указанных вопросов необходимо владеть информацией о разновидности преступного мира, к которому принадлежит субъект, иметь представление о криминогенных особенностях, присущих представителям того или иного типа, а также о целесообразных способах воздействия на них

Таким образом, при условии осведомленности правоприменителя о совокупности тех или иных эндогенных факторов, присущих несовершеннолетнему, он может оказать положительное воздействие в контексте профилактики и превенции возможного последующего девиантного поведения.

Как отмечает И. Ф. Заболотный, практическое значение типологизации личности преступников связывается, прежде всего, с возможностью диффференцировать профилактическое и карательно-воспитательное воздействие, решать некоторые следственные задачи, выявлять и анализировать отдельные типы преступного поведения, а также объяснять это поведение особенностями определенного типа личности [4].

Типологизация лиц, вставших на преступный путь, обусловлена необходимостью сведения их в однотипные группы, так как для того, чтобы более глубоко изучить личность преступника и ее структурированность, необходимо познать и типичное в такой личности.

Совершение преступления является конечным «маршрутом» несовершеннолетнего лица, предшествует же ему совокупность фракторов: жизнь, состоящая из микро и макросред. негативные черты характера и качества, которые в конкретной ситуации и предопределяют общественно опасный поведенческий тип.

Исследователи К. Е. Игошев и Г. М. Миньковский полагают, что само это поведение есть «не что иное, как реализация вовне (объективизация) определенных сторон, свойств внутреннего мира данной личности [5].

Преступление как негативное социальное явление имеет под собой два корня. Один произрастает из личности ювенального преступника, другой из внешней действительности, т.е., так называемые, микро и макросреды. Те элементы, из которых слагается «личный» корень преступления, можно назвать «эндогенными» факторами, а внешние обстоятельства, которые побуждают субъекта совершить преступление - «экзогенными» [7].

Автор исследования полагает, что каждое преступление является результатом взаимодействия как эндогенных, так и экзогенных факторов, иными словами - есть результат многофакторной детерминации - в одних преступлениях доминирующая роль принадлежит эндогенным, в другихнаоборот.

Однако совершение преступления всегда обусловлено системой факторов - создайте условно цепочку внешних событий, под прессом которых произошло преступление, необходимо прибавить личность с её индивидуальным складом характера. Так, личность иного склада, при тождественных внешних обстоятельствах, совершит иное преступление или вовсе откажется от становления на преступный путь.

Изучение криминологической литературы свидетельствует о том, что представители доктрины, по общему правилу, выделяют четыре типа ювенальных преступников, для которых совершение преступления было: 1) случайным (рандомным), противоречащим общей природе личности; 2) ситуационным, т.е. совершенным вследствие общей неустойчивости личностной направленности; 3) соответствующим общей направленности личности, но рандомным с точки зрения ситуации и мотива; 4) соответствующей личностной психологической установке и включающим нацеленные действия по созданию преступной ситуации (иногда искусственно)

В зависимости от конкретного исследователя, каждый ставит «во главу угла» различные признаки (признак) в качестве доминирующих критериев дифференциации типов личности, как-то: психологический, социальный, экономический, политический, национальный и др. 
В рамках настоящего исследования, автор предлагает дифференциацию несовершеннолетних преступников на типы исходя из криминоло-психологического и мотивационного критериев.

1. Экспансивные (инстинктивные) преступники

К указанному типу относятся индивидуумы, которые ценою преступления готовы купить удовольствие, удовлетворить различные потребности. Такому типу не свойственен глубокий анализ, осознанность, а также построение цепочки причинно-следственной связи между содеянным, и последствиями, которые вероятно могут наступить.

В момент совершения преступления такие индивидуумы могут относиться к последствиям индифферентно либо легкомысленно, полагая, что им удастся избежать правосудия и остаться «ЧИстыми».

Нередко это мнение обусловлено слепой верой в профессионализм и ловкость сотоварищей, которые часто оказываются людьми бывалыми, знающими как быстро и легко «сухими выйти из воды»

Несовершеннолетние без крепкого внутреннего стержня и осознанности, как правило, соглашаются, впоследствии, может прийти осознание содеянного и раскаяние.

В рамках настоящего исследования информативные материалы, касающиеся конкретных людей, заимствованы из рукописей и набросков доктора юридических наук и профессора кафедры уголовного права и процесса Чечель Григория Ивановича (в целях сохранения конфиденциальности, имена собственные в конкретных примерах изменены).

Александр Р., 17 лет, уроженец г. Ростов-на-Дону, сожительствует с Л., имеет на иждивении малолетнего ребёнка, осуществлял трудовую деятельность в качестве электрика на неофициальной основе. Некто Ш. пригласил его поправить у себя электрическое освещение, позднее разговорился с ним и продолжал общение после починки электричества. Познакомившись поближе, он предложил ему совершить грабеж под видом проведения следственного действия «осмотр места происшествия, местности, жилища, иного помещения, предметов и документов». Александр Р. без колебаний согласился, веря, что дело «сойдет с рук» и он останется безнаказанным. C фальсифицированным постановлением о разрешении проведения следственного действия осмотра жилища, они вдвоем прибыли в квартиру Г., причем, Ш. производил обыск, а Александр Р. составлял протокол. Впоследствии, с награбленными деньгами, драгоценностями прибыли в квартиру Ш. Позднее, после правозглашения по данному уголовному делу приговора суда, Александр пояснил, что он воспринял его вполне спокойно. Александр производит впечатление человека безучастного, спокойного и интеллигентного. В условиях изоляции от общества размышлял о том, что нанес своей семье вред, в тот момент, когда он решился на преступление, говорит, что о наказании много не думал, полагал, что, в крайнем случае, «дадут год, не более».

Автор приходит к выводу, что тип - инстинктивные преступники решается на преступление без особой нравственной, внутренней борьбы, и не только, когда испытывает нужду. Иногда он действует под влиянием неожиданно вспыхнувшей или навязанной (подкинутой) кем-либо идеи.

Предлагаем дифференцировать тип экспансивных (инстинктивных) преступников на подтипы.

1.1. Самолюбиво-амбициозные экспансивные преступники

Так, некоторые индивидуумы готовы встать на преступный путь, исходя из соображения произвести впечатление, как говорится «показать себя». Таким подтипом людей руководит преимущественно тщеславие, «ложное» самолюбие. Им присуща закомплексованность, чрезмерная обидчивость, а также навязчивая идея не показаться в глазах других неудачником.

Такой подтип способен пойти на преступление порой тяжкое или особо тяжкое, если жертва затронет самолюбие, иногда это может быть самый незначительный повод, который спровоцирует совершение преступления

Иван Ж., 17 лет, уроженец г. Екатеринбург, шел по улице и впереди себя заметил девушку лет 30 , при виде которой у него внезапно возник умысел на совершение преступления. Догнав её, он завел беседу, предложил помочь донести сумки немного позднее нанес своей спутнице 7 ударов камнем по голове, схватил сумки и скрылся. Придя домой, он передал похищенные вещи матери, сказав, что это подарок от тети. Анализируя условия жизни Ивана, приходим к выводу, что отец его держал фермерское хозяйство, у матери была домработница. Родители Ивана часто ссорились, мать ругала отца за пьянство. Вскоре отец скончался. Иван закончил школу, учился средне. Детство в целом протекало без потрясений, семья не бедствовала. Половой жизнью Иван не жил. Перед тем как совершить разбойное нападение, его уволил родной дядя. В связи с указанным событием Иван был очень опечален - чувствовал себя униженным. Он осознавал, что мать расстроится, если узнает правду. По этой-то причине, дабы не возвращаться домой с «пустыми руками», он решил хоть как-то «подзаработать».

В этом и кроется, по нашему мнению, ключ к распознанию корня указанного преступления. Несовершеннолетнее лицо, будучи на хорошем счету, не допуская ранее «проколов», был уволен, тем более, родным дядей. Что касается осознания содеянного впоследствии, то Иван указывает, что себя осуждает, однако не по причине нравственного зова, а по причине невыгодности преступления для него самого - «опозорил себя и будут теперь пальцем тыкать». Поясняет, что сначала ударил девушку камнем, и когда она упала и закричала, с испугу начал хаотично наносить многочисленные удары по голове. Впоследствии, по возвращении домой, произошедшему не придал значения и занялся своими делами. 
Вину признал в ходе проведения очных ставок с потерпевшей. О содеянном нередко вспоминает но подходит сугубо с рациональной точки зрения как на него будут люди смотреть, что подумают Раскаяния и сожаления к потерпевшей не испытывал, испытывал страх перед «Буквой Закона» Производил самоанализ, что человека убивать нельзя, однако указанный самоанализ не имеет никакой эмоциональной окраски.

1.2. Сребролюбивые экспансивные преступники

Следующий подтип инстинктивных преступников составляют те, которые готовы встать на преступный путь ради материального блага - красивой вещи, утвари, с целью украсить себя лично (дорогая одежда, обувь, драгоценности) или домашней утвари (редкая ваза, ковер, сервиз и др.).

Яков Л., 17,5 лет, уроженец г. Краснодар, совершил разбойное нападение группой лиц с целью заполучить новую одежду к предстоящему важному мероприятию. Яков Л. работал пекарем у отца в булочной. Семья была материально обеспечена, однако отец злоупотреблял распитием спиртных напитков и большую часть доходов пропивал. Яков Л., совершая преступление осознавал степень и характер противоправной деятельности, имел среднее образование, увлекался чтением классической литературы, однако отец давал мало карманных денег, а Яков любил принарядиться, «показать себя). Следовательно, приближение праздников обусловило возникшую потребность в новом костюме и карманных деньгах посредством совершения преступления.

Также следует привести пример о том, как желание добыть себе обувь высокого качества, побудило двоих несовершеннолетних - Дмитрия В. и Станислава К. совершить преступление а именно в три часа ночи напасть на пожилого человека в селе и ограбить его. Вначале они избили потерпевшего, затем отняли ценные вещи и скрылись с места преступления. Несовершеннолетние - легкомысленные по своей натуре люди, любят погулять и развлечься. Чувство самоанализа осознанности, нравственно-моральный стержень им не свойственны, страсть к материальным вещам является доминирующей в характере

\section{3. Праздные экспансивные преступники}

Указанный подтип совершает преступления с целью получить средства для какого-либо развлечения, как-то: пойти в клуб, ресторан, приобрести наркотическое средство, алкоголь и прочее.

Дмитрий К., 16,5 лет, уроженец г. Михайловска согласился принять участие в убийстве семьи А. так как у него не хватало средств на алкоголь а родители не давали карманных денег. Семья А была дальними знакомыми Дмитрия К., открыли дверь, сначала все выпили, а затем началась «бойня», в результате которой Дмитрий К. «перебил» четырех человек.

Олег Е., 17,3 лет, уроженец г. Ростова-на-Дону, - молодой человек достаточно ленивый и апатичный по своей натуре. Отец его занимался изготовлением обуви, мать была домохозяйкой
Родители находились в напряженных отношениях, так как отец злоупотреблял распитием спиртных напитков, наносил побои всем членам семьи. Из 6 человек выжили четверо, из которых - два сына, две младших дочери. Отца Олег избегал, ненавидел за причинение ему физической боли, однако с 9 лет отец разрешал Олегу употреблять спиртные напитки, а именно водку, затем разрешил курить сигареты. Когда Олегу было 9,5 лет отец умер. Мать и старший брат старались вывести Олега в люди, отвели к психологу, записали на спортивные секции. Однако учёба давалась слабо, впоследствии, после окончания девяти классов, устроиться на работу не предпринимал попыток, жил за счёт родственников. Олег любитель развлечений - любил посещать питейные заведения, клубы, пробовал торговать несертифицированной алкогольной продукцией, однако из-за пагубного пристрастия потреблял все самостоятельно. Начал совершать кражи, грабежи. Договорившись с товарищем Л., решили произвести ограбление квартиры. Людей, которые открыли дверь - ударили по голове кувалдой несколько раз и забрали материальные ценности. Впоследствии, Олега и Л. задержали и избрали меру пресечения в виде заключения под стражу.

Анализируя психотип Олега, приходим к выводу, что он корыстолюбивый, жестокий, с полным отсутствием нравственного стержня, склонен к праздной жизни. Основной мотив к совершению преступления - добыть денежные средства любым путем для удовлетворения потребностей в развлечениях.

1.4. Религиозно-фанатичные экспансивные преступники

Данный подтип характеризуется наличием чрезмерного интереса к религиозной литературе, догме, посещению святых мест, жертвованием денежных средств на благотворительность.

Однако чрезмерная «любовь» к религии омрачается агрессией и конфронтацией по отношению к тем, кто не разделяет данные взгляды, либо относится к ним крайне пренебрежительно/ индифрерентно.

Максим Т., 16,9 лет, уроженец г. Волгограда после посещения вечерней литургии, заметил, как некто Д. курил на территории храма, а, позднее, бросил окурок и плюнул. Максим Т., недолго думая, подошел к Д. и ударил его кирпичом по голове. От причиненных телесных повреждений потерпевший скончался на месте

Впоследствии, Максим Т. пояснил, что не мог допустить подобного неуважительного и наглого поведения к Богу. Свое поведение и поступок порицает, говорит, что агрессия и злоба затмила в тот момент всю присущую ему сознательность и анализ.

1.5. Экстремистские экспансивные преступники

Экстремизм (от лат. Extremus - крайний, чрезмерный) - приверженность крайним взглядам, методам действий. Как правило, экстремисты часто отрицают в принципе возможность достижения 
консенсуса. Увеличению экстремизма способствуют общественные катаклизмы, как-то: авторитарные политические режимы, социально-экономические кризисы, процессы инфляции и др.

Дефиниции «экстремизм», «экстремистская организация», «экстремистские материалы», получили закрепление в ст. 1 Федерального закона от 25.07.2002 г. № 114-Ф3 «О противодействии экстремистской деятельности) (источник обращения - Консультант-Плюс) [9].

Уголовный закон под преступлениями экстремистской направленности понимает преступления, совершенные по мотивам политической, идеологической, расовой, национальной или религиозной ненависти или вражды либо по мотивам ненависти или вражды в отношении какой-либо социальной группы.

В современном социуме функционирует большое количество партий, объединений, организаций, которые, по своей сути, являются экстремистскими. По своим идейным критериям, могут быть религиозного или политического цикла.

Несовершеннолетние лица, в частности, способствуют развитию и процветанию подобных объединений.

Как отмечает исследователь Ю. Н. Зеленов «молодежный экстремизм стал распространенным явлением» [5].

Несовершеннолетние лица представляют собой особую социальную касту, которая, как правило, не имеет четко устоявшегося личностного стержня, и, ввиду этого, склонна быть подверженной влиянию различных детерминант (социальных, религиозных, экономических, политических, культурных).

В подростковом возрасте, существующая реальность в сознании подростков окрашена особой цветовой гаммой - все события воспринимаются через призму обостренных чувств, эмоций, любое замечание или разговор позиционируются как попытка вторжения в личное пространство и способ ограничения личной свободы.

Кроме того, в подростковом возрасте, уровень внушаемости и доверчивости чрезвычайно высок, таких лиц легко завербовать, пообещать «золотые горы» и те, в силу возрастной «гибкости», дадут согласие.

Указанная специфика возрастных особенностей обусловливает многочисленность экстремистских групп.

Так, Алексей С., являясь жителем с. Безопасного, проживал в полной многодетной, малообеспеченной семье. Отец Алексея работал на фрерме у одного из жителей села, однако тот нашел работников цыганской национальности, требующих меньший размер оплаты труда, в связи с чем отец Алексея был уволен и стал злоупотреблять спиртными напитками.

С тех пор, Алексей начал считать, что все трудности, возникающие у его семьи, возникают по вине лиц, цыганской национальности.

В один из дней, Алексей, придя домой, застал отца в состоянии сильного алкогольного опьянения, после чего у него возник умысел на «расправу» с первыми попавшимися ему лицами цыганской национальности по причине рассовой ненависти.

В продолжение своего приступного умысла, Алексей вышел из дома, при этом взяв в руки металлический прут, после чего, подойдя к входной двери соседнего дома, в котором проживала цыганская семья, постучал в дверь. Входную дверь ему открыл отец семейства, после чего, Алексей нанес ему не менее пяти ударов указанным металлическим прутом по различным частям тела, причинив последнему тяжкий вред здоровью.

1.6. Развратно-экспансивные преступники

Указанному подтипу свойственна безудержная тяга к половым удовольствиям, их не останавливают морально-нравственные критерии, ключевым толчком к совершению преступлений является похоть. Подтип развратных преступников руководствуется преимущественно животными инстинктами, анализ и осознанность в контексте морали им не свойственны.

Павел Д., 17,7 лет, уроженец г. Краснодар, родители молодого парня злоупотребляли распитием спиртных напитков, отец нередко причинял физическую боль. Павел с 16 лет сожительствовал с молодыми девушками, а иногда и женщинами. Обращался с избранницами жестко и не понимал категорического слова «нет», когда речь шла о половом сношении. В результате, парню не хватало конкретной девушки (женщины) и он принуждал иных лиц к сексуальным действиям насильственного характера. «Бесперебойные» связи объясняет тем, что он натура влюбчивая и полигамная, на отказы женского пола реагировал неадекватно. Так, судебно-психиатрическая экспертиза установила диагноз - нервное расстройство на почве врожденной психопатии с извращениями в области сексуальной сферы.

1.7. Альтруистические и антиальтруистические экспансивные преступники

Преступники альтруисты - подтип, действующий ради удовлетворения альтруистического долга, желание служить другим людям, доставлять им удовольствие, дарить радость и т.д. и т.п. (во имя любви, дружбы, долга, сострадания и др.)

Преступники антиальтруисты - подтип, действующий ради удовлетворения альтруистического долга, желание угождать одним, причиняя вред другим. В основе лежит негативная эмоция злоба, месть, ревность, агрессия и др.

Андрей Г., 16,5 лет, уроженец г. Ставрополя проживал совместно с матерью, отчимом и престарелой бабушкой, которая являлась инвалидом первой группы. Отчим злоупотреблял распитием спиртных напитков, применял физическую силу по отношению к родным, в особенности, к матери, унижал, психологически подавлял и держал, как говорится, в страхе всю семью. Андрей Г. долго молчал, с отчимом не пререкался, так как мать велела вести себя подобным образом. В один из будних дней, отчим вернулся домой в состоянии сильного алкогольного опьянения, начал оскорблять бабушку и мать, затем начал поднимать руку на последних. Несовершеннолетний в 
тот момент осознавал, что если подобную нежелательную активность не пресечь, то с каждым разом она будет набирать обороты и может привести к трагедии. Находясь в состоянии шока и перевозбуждения, он взял стеклянную вазу и нанес несколько ударов по голове отчиму, от чего последний получил черепно-мозговую травму по квалифицирующему признаку - тяжкий вред здоровью. Впоследствии, Андрей раскаялся, сожалел о содеянном, однако мать и бабушку ему было жаль в большей степени, и он чувствовал свой долг защитить последних.

Указанные подтипы альтруистов и антиальтруистов можно дифференцировать детальнее по принципу видовых подтипов, беря за основу руководящую эмоцию - экспансивные альтруисты агрессоры, ревнивцы, мстители, завистники, раздражительные; по виду афффективные и эмоционально-осознанные - действия первых обусловлены «порывом», «зовом» чувства, сознание затуманено, функция анализа временно приостановлена.

Действия вторых обусловлены аффектированным состоянием, однако одновременно сохраняются элементы осознанности и прогнозирования

Самуил Ж., 17,5 лет, уроженец г. Кисловодска ухаживал за девушкой еврейской национальности. По истечении нескольких месяцев после знакомства, принял решение жениться на девушке Мать Самуила была против брака, постоянно ссорилась с семьей невесты, делала замечания и упрекала родителей девушки, что это они «заловили» молодого человека, а про родного сына говорила, что он легкомысленный, неряшливый, по-настоящему любить не способен и т.д. и т.п. На сына мать пыталась воздействовать разными способами: отказывалась стирать, готовить, выдавать карманные деньги. В связи с этим, у матери и сына были постоянные конфликты, скандалы, которые 20.02.2015 г. привели к трагедии 19.02.2015 г. Самуил проснулся, зашел в гости к невесте, затем на учёбу. Вернувшись вечером, он узнал, что его мать ворвалась с щипцами для волос в квартиру невесты, схватила за волосы невесту и ударила ее мать по лицу. Родители невесты упрекали Самуила, что он не может «обуздать» родную мать» и является бесхарактерным. Весь вечер Самуил пробыл у невесты, покинул ее дом в 11 часов вечера с четким намерением убить мать - задушив её, как только она откроет ему дверь. Однако, когда мать открыла дверь, он не смог воплотить задуманное в реальность, умылся и пошел спать. Но уснуть не получалось, вспоминались все нанесенные обиды, юноша злился и плакал.

Ночью у него окончательно созрел план по убийству матери, который он тщательно проработал на ментальном уровне. В 4 часа утра парень встал, прокрался в комнату матери, взял ключ от гаража, откуда впоследствии он взял деревянную доску, которой нанес ей несколько ударов по голове. От стонов матери проснулся спавший в соседней комнате младший брат, попытался войти в комнату к матери, однако Самуил преградил путь, сказав: «маме плохо, беги за доктором». Послав брата за доктором, который жил этажом ниже, Самуил хотел сымитировать ограбление: сорвал дверной замок, открыл окно, молотком разломал деревянный шкаф, разбросал вещи и др. Позднее, он выскочил на улицу с криком: «у нас налет»», «мать убили!», начал будить соседей, просить, чтобы осуществили вызов кареты скорой помощи. Потерпевшая, не придя в сознание, скончалась.

Несовершеннолетнего осудили к 8 годам лишения свободы.

Знакомясь с личностью Самуила, мы узнаем, что отец его злоупотреблял распитием спиртных напитков, был раздражительным, постоянно ссорился с матерью, иногда применял физическую силу. Семья была конфликтная, отношения с отцом у парня были хорошие, а с матерью, братом и сестрой - натянутые. Мать ненавидел в течение многих лет. Как он пояснял, любил он искренне только невесту. Материальных затруднений в целом он не испытывал, однако в результате длительной психотравмирующей ситуации ссрормировался перечень доминирующих негативных черт - мстительность, раздражительность, вспыльчивость, злоба. Впоследствии, в содеянном раскаялся, пояснил, что «какая они ни была, все-таки мать», и он не должен был поступать таким образом. Испытывает угрызения совести, что оставил брата и сестру без матери.

Доминирующей негативной чертой являлась мстительность. Самуил мог избрать иной ненасильственный способ выражения протеста - переехать от матери и прекратить общение, однако сделал выбор в пользу становления на преступный путь.

\section{2. Консеквентные преступники}

Представителями указанного типа являются преступники, которые, поставив перед собой цель - достижение высокого положения, как-то: социального, служебного, материального, семейного, готовы встать на преступный путь и совершить преступление на благо достижения «высокой» цели. Корнем преступного деяния, в данном случае, является целеполагание, которое предполагает наличие в себе ряда подцелей, задач, рассчитанных на длительный временной промежуток.

Таким образом, консеквентный преступник является антиподом экспансивному преступнику, его действия не обусловливаются внезапным порывом эмоций и чувств. В данном случае речь идет о целеполагании и тщательной подготовке, взвешивании всех «за» и «против».

В качестве целеполаганий можно выделить следующие виды: 1) карьеризм; 2) достижение высокого материального статуса; 3) иное.

Валерий К., 17,5 лет, уроженец г. Саратов, проживал совместно с родителями, которые занимались торговлей. Семья была материально обеспеченной и юноша не знал нужды. Половую жизнь Валерий начал вести рано, в основном, имел мимолетные связи. В 17 лет начал сожительствовать с Е., 23 г., которая осуществляла 
трудовую деятельность в качестве продавца в бакалейной, в скором времени девушка забеременела. Е. очень волновал материальный вопрос, так как молодая пара жила в общежитии в одной комнате и имела небольшой совокупный доход. Родители Валерия не помогали, так как последний испортил с ними отношения.

Валерий и Е. на почве недостатка денежных средств постоянно ругались, он начал распивать спиртные напитки, поднимать на нее руку, когда та находилась в положении. Вдобавок девушка была очень ревнивой и угрожала Валерию время от времени прыснуть в лицо кислотой. Данной угрозы парень опасался и воспринимал её как реальную. 30.03.2013 г., Валерий проснулся достаточно поздно, выслушал все недовольства сожительницы, он хотел её избить, однако удержался. Днем парень вышел и вернулся уже вечером в состоянии алкогольного опьянения. Молодые люди снова сели за стол и начали ругаться, начались угрозы прысканьем «кислотой», судом и прочим. Валерий выскочил из-за стола взвинченный, хотел убить, но сдержался. Последующие часы он обдумывал план убийства, пытался вызвать раскаяние у сожительницы за неуважительное к нему отношение, однако девушка «не каялась».

Перед сном, сказал Е. - «ну ладно, пойду закурю», встал и пошел к столу, на котором лежали сигареты и нож. Парень спрятал нож в рукав, лег рядом с E., ещё раз спросил её, согласна ли она попросить прощения и, получив отрицательный ответ, сказал: «Е., у тебя одеяло сползло, дай поправлю», обнял девушку, достал нож из рукава и резнул по горлу. Ни испуганного лица, ни криков Валерий не заметил, только один хрип. Перерезав сожительнице горло, он перевалил её на правый бок и «дорезал». Позднее, повалил девушку на пол, сам сел на кровать и, почувствовав сильную усталость и боль в глазах - уснул. Проспал около 7 часов, встал, позавтракал, отправился по делам. Вернувшись домой - пообедал и принялся за сокрытие следов преступления: разрезал труп на части, разрубил кости топором, тело поместил в мешок и бросил в реку. Так, обеспокоенные соседи начали искать Е., так как та часто навещала их и жаловалась на сожителя. Вечером, одна из соседок позвонила в полицию и когда сотрудники вошли в комнату, то увидели, что Валерий пытался ликвидировать следы преступления: оттирал кровь, стирал вещи, пропитанные кровью жертвы. Впоследствии, всю процедуру убийства рассказывает абсолютно спокойно, мотивирует свой поступок тем, что боялся, что с него будут в судебном порядке взыскивать алименты, он вынужден будет нести и иные расходы, пока Е. будет находиться в декретном отпуске. Также поясняет, что в содеянном не раскаивается, о Е. и ребенке не вспоминает, с нравственной точки зрения никакого анализа не производит.

Не отрицает, что убийство - тяжкий грех и перед Всевышним и перед людьми, однако если человек «не вреден», а в обратном случае - «какой же тут грех», - говорит он. Покойная Е. была чрезмерно ревнива, характерна, угрожала ему.
«Избавился от такой сволочи и ладно, зарезал и из головы долой».

В данном случае, поразительно то, с каким равнодушием Валерий относится как к судьбе собственного не рождённого ребенка, так и его матери. Доминирующими чертами являются жестокость, неудовлетворенность, злоба и ненависть к окружающим.

Таким образом, в современном мире сосуществует великое множество преступников, каждый из которых, характеризуется уникальным набором качеств, свойств и особенностей и только способность (компетенция) разбираться в психотипах ювенальных преступников может оказать благотворное воздействие в контексте профилактики и минимизации подростковой преступности.

Так, при системном анализе материального и процессуального права, регламентирующего особенности уголовной ответственности несовершеннолетних, приходим к выводу, что отсутствует прямая императивная обязанность производства комплексной психолого-психиатрической экспертизы в отношении несовершеннолетнего преступника.

В статье 421 УПК РФ указано, что при наличии данных, свидетельствующих об отставании в психическом развитии, не связанном с психическим расстройством, устанавливается также, мог ли несовершеннолетний в полной мере осознавать фактический характер и общественную опасность своих действий (бездействия) либо руководить ими (ч. 2).

Медицинское освидетельствование несовершеннолетнего проводится в ходе предварительного расследования на основании постановления должностного лица. Заключение о результатах медицинского освидетельствования несовершеннолетнего представляется в суд с материалами уголовного дела [8].

Из буквального толкования нормы следует, что для выяснения обстоятельств: «понимал ли несовершеннолетний характер своих действий?», «был ли способен руководить своими действиями?», необходимо “наличие данных, свидетельствующих об отставании в психическом развитии».

В чём должны быть выражены (объективизированы) эти некие данные, кем должен быть удостоверен данный факт, остается неурегулированным в рамках правового поля.

Более того, несовершеннолетнее лицо могло столкнуться с проблемами в психо-эмоциональной сфере, однако родители не обращались ранее за медицинской помощью и указанный факт не удостоверен надлежащим образом, либо заболевание протекает сугубо латентно и родители вместе с чадом не подозревают о его существовании, так как отклонения могут быть диагностированы только специалистом

Например, в психиатрии имеется разновидность заболевания, так называемая, латентная шизофрения - форма шизофрении, протекающая с «лёгкими патологическими расстройствами», с отсутствием психотической симптоматики [2] 
Так, Герман Роршах обозначал термином «латентная шизофрения» внешне адекватно функционирующих лиц, которые на его тесты отвечали так же, как больные шизофренией [1].

Как правило, психотической симптоматики при скрытой шизофрении не наблюдается, однако она может проявиться после длительного скрытого течения расстройства или под влиянием негативных факторов, как-то: травма головы, стресс, депрессия, смерть близкого и прочее).

Вызывает интерес тот фракт, что сама диагностика скрытой формы шизофрении с шизоидным расстройством личности сопряжена с трудностями [3]

В исследуемой норме делается ссылка на медицинское освидетельствование, однако конкретизация по виду отсутствует, несмотря на то, что в Федеральном законе от 21.11.2011 № 323-Ф3 «Об основах охраны здоровья граждан в Российской Федерации» содержатся многочисленные виды [10].

В связи с этим, полагаем необходимо внести корректировку в норму и указать на конкретный вид освидетельствования: «медицинское освидетельствование несовершеннолетнего на наличие или отсутствие у него заболевания, препятствующего его содержанию и обучению в специальном учебно-воспитательном учреждении закрытого типа».

Исследуемая норма также обязывает устанавливать наличие или отсутствие у несовершеннолетнего заболевания, препятствующего его содержанию и обучению в специализированном учреждении, для рассмотрения судом вопроса о возможности освобождения несовершеннолетнего от наказания и направлении его в указанное учреждение (ч. 3 ст. 421 УПК РФ).

Указанные обстоятельства подлежат установлению, если подросток совершил преступление средней тяжести или тяжкое преступление. А как быть с преступлениями иных категорий - небольшой тяжести и особо тяжкими? Если у подростка имеется заболевание, однако он совершил преступление небольшой степени тяжести, тогда по логике законодателя он не нуждается в освидетельствовании

В этой связи полагаем необходимым внести изменения в действующую редакцию статьи 421 и указать на необходимость проведения не медицинского освидетельствования, а самостоятельной психолого-психиатрической экспертизы: «в отношении несовершеннолетних, совершивших преступления небольшой, средней степени тяжести, тяжкое либо особо тяжкое, надлежит проведение комплексной психоло-психиатрической экспертизы, вне зависимости от того, имеется ли в отношении конкретного лица информация об отставании в психическом развитии».

Кроме того, считаем необходимым в рамках проведения психоло-психиатрической экспертизы подготавливать некую социально-педагогическую реабилитационную программу, к которой следует обращаться правоприменителям при взаимодействии с несовершеннолетним, что будет способствовать скорейшей ресоциализации ювенальных преступников

В целях более глубокой и эффективной ресоциализации несовершеннолетнего, также предлагаем создание специализированных курсов, нацеленных на психолого-педагогическую коррекцию осужденных, которая будет включать проработку внутренних личностных противоречий, детских травм, закомплексованности и прочих негативных явлений. Указанные курсы могут проводится на базе психиатрических больниц, клиник пограничных состояний, а в качестве преподавателей (коучеров) могли бы выступать студенты-практиканты.

Таким образом, коучинг подобного рода, по мнению автора, будет способствовать действительной, а не номинальной ресоциализации ювенального преступника.

Резюмируя вышеизложенное, подведем итоги исследования:

1) автор предлагает дифференциацию несовершеннолетних преступников исходя из психолого-мотивационного критерия на два типа: экспансивные (инстинктивные) и консеквентные преступники, каждый из которых подразделяется на подтипы исходя из особенностей психологического портрета личности, мотивации и идеи как критериев совершения преступления;

2) предлагается внесение изменений в действующую редакцию статьи 421 Уголовно-процессуального кодекса РФ посредством закрепления обязанности проведения комплексной психолого-психиатрической экспертизы в отношении несовершеннолетнего, ввиду существования многих заболеваний, протекающих латентно и диагностируемых только специалистом.

3) Автор предлагает создание специализированных социально-педагогических реабилитационных программ в рамках проведения судебно-медицинских экспертиз, которыми следует руководствоваться правоприменителям при взаимодействии с несовершеннолетним, что будет способствовать скорейшей ресоциализации ювенальных преступников.

4) Также автором высказано предложение о создании специализированных курсов на бесплатной основе, нацеленных на психолого-педагогическую коррекцию несовершеннолетних осужденных, которая будет включать проработку внутренних личностных противоречий, детских травм, закомплексованности и прочих негативных явлений. Указанные курсы могут проводиться на базе психиатрических больниц, клиник пограничных состояний, а в качестве преподавателей (коучеров) могли бы выступать студенты-практиканты.

Таким образом, грамотная типологизация несовершеннолетних преступников, создание благоприятных условий для социального «выздоровления" и принятие в купе эфффективных мер может способствовать реальной ресоциализации лица, вставшего на преступный путь. 


\section{Литература}

1. Вид В.Д. Психотерапия шизофрении. URL: https://www.piter.com/product/psihoterapiya-shizofrenii-3-e-izd. (Дата обращения: 21.09.2018)

2. Блейхер В. М., Крук И. В. Шизофрения латентная URL: http://pedlib.ru/Books/4/0363/4_0363-1.shtml. (Дата обращения: 21.09 .2018 )

3. Жмуров В.А. Психиатрия. Энциклопедия - T/O М.: «Neformat», 2016. 341 с.

4. Заболотный И. Ф. Причины современной преступности несовершеннолетних и её предупреждение. М.: Юридлит, 2004. $296 \mathrm{c}$.

5. Зеленов Ю. Н. Педагогическая профилактика экстремистских проявлений в молодежной среде: монография. М.: ВНИИ МВД России, 2013. 63 с.

6. Игошев К. Е., Миньковский Г. М. Семья. Дети. Школа. М.: Юридлит, 1989. 448 с.

7. Криминальная психология «Преступные типы» / под ред. Познышева С. В. М.: Издательство Юрайт, 2019. 292 с

8. Федеральный закон от 18.12.2001 г. №174-Ф3 «Уголовно-процессуальный кодекс Российской Федерации» URL http://www.consultant.ru/document/cons_doc_LAW_34481/ (Дата обращения: 21.09.2018).

9. Федеральный закон от 25.07.2002 г. № 114-Ф3 «О противодействии экстремистской деятельности» URL: http:// www.consultant.ru/document/cons_doc_LAW_37867/. (Дата обращения: 21.09.2018).

10. Федеральный закон от 21.11.2011 № 323-Ф3 «Об основах охраны здоровья граждан в Российской Федерации» URL: http://www.consultant.ru/document/cons_doc_LAW_121895/. (Дата обращения: 21.09.2018)

\section{References}

1. Vid V.D. Psihoterapija shizofrenii (Psychotherapy of Schizophrenia) URL: https://www. piter.com/product/psihoterapiyashizofrenii-3-e-izd. (Accessed: 21.09.2018) (In Russian)

2. Blejher V. M., Kruk I. V. Shizofrenija latentnaja (Latent Schizophrenia) URL: http://pedlib.ru/Books/4/0363/4_0363-1. shtml. (Accessed: 21.09.2018) (In Russian)

3. Zhmurov V. A. Psihiatrija. Jenciklopedija - T/O (Psychiatry. Encyclopedia). Moscow: «Neformat), 2016. 341 p. (In Russian)

4. Zabolotnyj I. F. Prichiny sovremennoj prestupnosti nesovershennoletnih i ejo preduprezhdenie (The Reasons for Modern Crime of Minors and its Prevention). Moscow: Juridlit, 2004. 296 p. (In Russian)

5. Zelenov Ju. N. Pedagogicheskaja profilaktika jekstremistskih projavlenij v molodezhnoj srede (Pedagogical Prevention of Extremist Manifestations among Young People). Moscow, 2013.63 p. (In Russian)

6. Igoshev K. E., Min'kovskij G. M. Sem'ja. Deti. Shkola (Family. Children. School). Moscow: Juridlit, 1989. 448 p. (In Russian)

7. Kriminal'naja psihologija «Prestupnye tipy» (Criminal Types) / ed by Poznyshev S.V. Moscow: Jurajt, 2019. 292 p. (In Russian)

8. Federal'nyj zakon ot 18.12 .2001 g. №174-FZ «Ugolovno-processual'nyj kodeks Rossijskoj Federacii) (Criminal Procedure Code of the Russian Federation) URL: http://www.consultant.ru/document/cons_doc_LAW_34481/ (Accessed: 21.09.2018).

9. Federal'nyj zakon ot $25.07 .2002 \mathrm{~g}$. № 114-FZ «O protivodejstvii jekstremistskoj dejatel'nosti» (On Counteraction to Extremist Activity) URL: http://www.consultant.ru/document/cons_doc_LAW_37867/. (Accessed: 21.09.2018).

10. Federal'nyj zakon ot 21.11.2011 № 323-FZ «Ob osnovah ohrany zdorov'ja grazhdan v Rossijskoj Federacii» (On the Basis of Health Protection in the Russian Federation) URL: http://www.consultant.ru/document/cons_doc_LAW_121895/. (Accessed: 21.09.2018)

Сведения об авторе

Каледин Максим Евгеньевич - аспирант кафедры уголовного права юридического института Северо-Кавказского федерального университета (Ставрополь) / zamnianc@mail.ru

Information about the author

Kaledin Maksim - post graduate student, Chair of Criminal Law, Institute of Law, North-Caucasus Federal University (Stavropol) / zamnianc@mail.ru 